Original article

\title{
Impact of locoregional treatment on survival in patients presented with metastatic breast carcinoma
}

\author{
Melis Gultekin ${ }^{a}$, Ozan Yazici ${ }^{b}$, Gulnihan Eren ${ }^{a}$, Deniz Yuce ${ }^{c}$, Sercan Aksoy ${ }^{\text {d }}$, \\ Yavuz Ozisik ${ }^{\mathrm{d}}$, Nilufer Guler ${ }^{\mathrm{d}}$, Gozde Yazici ${ }^{\mathrm{a}}$, Pervin Hurmuz ${ }^{\mathrm{a}}$, Ferah Yildiz ${ }^{\mathrm{a}, ~}$, \\ Kadri Altundag ${ }^{\mathrm{d}}$, Murat Gurkaynak ${ }^{\mathrm{a}}$ \\ ${ }^{a}$ Department of Radiation Oncology, Faculty of Medicine, Hacettepe University, 06100 Ankara, Turkey \\ ${ }^{\mathrm{b}}$ Medical Oncology Clinic, Education and Research Hospital, Ankara Numune Hospital, Ankara, Turkey \\ c Department of Preventive Oncology, Cancer Institute, Hacettepe University, Ankara, Turkey \\ d Department of Medical Oncology, Cancer Institute, Hacettepe University, Ankara, Turkey
}

\section{A R T I C L E I N F O}

\section{Article history:}

Received 5 April 2014

Received in revised form

6 August 2014

Accepted 11 August 2014

Available online 5 September 2014

\section{Keywords:}

Metastatic breast carcinoma

Locoregional treatment

Radiotherapy

Surgery

Chemotherapy

\begin{abstract}
A B S T R A C T
Objectives: In this study, we tried to evaluate the efficacy of locoregional treatment (LRT) in patients with metastatic breast carcinoma (MBC).

Materials and methods: The medical records of 227 patients with MBC at initial presentation between April 1999 and January 2013 were retrospectively evaluated. The median age at diagnosis was 50 years (range, 27-83 years). Thirty-nine patients (17\%) had no LRT. Among patients who had LRT, 2 (1\%) had locoregional radiotherapy (RT) alone, 54 (29\%) had surgery alone [mastectomy, $n=50$; breast conserving surgery (BCS), $n=4$ ] and $132(70 \%)$ had surgery (mastectomy, $n=119$; BCS, $n=13$ ) followed by locoregional RT.

Results: The median follow-up time was 35 months (range, 4-149 months). Five-year OS and PFS rates were $44 \%$ and $20 \%$, respectively. In both univariate and multivariate analysis LRT per se did not affect OS and PFS rates. However, the 5-year OS and PFS rates were significantly higher in patients treated with locoregional RT than the ones who were not. The corresponding rates were $56 \%$ vs. $24 \%$ for OS and $27 \%$ vs. $7 \%$ for PFS $(p<0.001)$. Median survival was 67 months and 37 months, respectively.

Conclusion: Our study showed that patients with MBC who received postoperative locoregional RT may have a survival advantage compared with patients who were only treated by surgery. A phase III trial testing the role of adjuvant locoregional RT may help to distinguish patients who will benefit from adjuvant RT.
\end{abstract}

(C) 2014 Elsevier Ltd. All rights reserved.

\section{Introduction}

Metastasis at the time of diagnosis has been observed in 3-10\% of women with breast carcinoma and it has been traditionally considered to be an incurable disease [1]. Median survival of these patients has been reported to be in the range of 16-24 months though some patients have been reported to have prolonged survival $[2,3]$.

Generally these patients had been treated by systemic treatment either as chemotherapy or hormonal therapy and locoregional treatment (LRT) had been traditionally reserved for patients with symptomatic tumors as with bleeding, ulceration or pain [4].

\footnotetext{
* Corresponding author. Tel.: +90 312 3052900; fax: +90 3123092914 .

E-mail address: fyildiz@hacettepe.edu.tr (F. Yildiz).
}

However, in recent years with the introduction of more effective systemic therapies such as taxane-based chemotherapy, aromatase inhibitors or targeted therapies as trastuzumab or bevacizumab, patients with metastatic disease are observed to live longer and even some live more than a decade $[5,6]$. Several retrospective studies including Surveillance, Epidemiology, and End Results (SEER) 1988-2003 database analysis showed that local therapy improved survival rates in these patients [6-17]. More recently, two randomized trials were presented in the San Antonio Breast Cancer Symposium, one from India and one from Turkey evaluated the efficacy of local treatment in patients with metastatic breast cancer (MBC) $[18,19]$. There are also ongoing studies from United States, Austria and Netherlands evaluating the role of local treatment in patients with metastasis at diagnosis [20]. Hopefully the long term results of these phase III trials will highlight which patients will most likely benefit from LRT. 
In our retrospective study, we tried to evaluate the efficacy of LRT in patients with MBC and to find out whether adjuvant locoregional radiotherapy (RT) further improved the survival rates.

\section{Materials and methods}

The medical records of 227 patients with MBC at initial presentation between April 1999 and January 2013 in our institute were retrospectively evaluated. LRT is defined as surgery and/or RT of the primary tumor and regional lymph nodes. This retrospective study was approved by the institutional ethics committee. Followup information was obtained from the patient charts, any hospital notes, referring doctors, general directorate of population and citizenship affairs, and as a last resort, from patients and/or next of kin.

Patient, tumor and treatment characteristics used for this analysis included the following: age at diagnosis ( $<50$ years vs. $\geq 50$ years), menopausal status, grade, histological subtype (ductal, lobular, other), T stage (T1-2 vs. T3-4) and N stage (N0 vs. N+), estrogen receptor (ER), progesterone receptor (PR), and HER2/neu status (positive vs. negative vs. unknown), metastatic sites (boneonly vs. others), visceral metastases (yes vs. no), and number (solitary vs. multiple) of metastases, use of hormonal therapy, chemotherapy, RT, type of surgery [mastectomy vs. breast conserving surgery (BCS)], timing of LRT, RT volume [breast/chest wall $(\mathrm{CW}) \pm$ lymphatic] and response to systemic therapy. All the patient and treatment characteristics are listed in Tables 1 and 2.

Patients were analyzed based on primary treatment: those who had LRT versus who did not, those who received RT versus those who did not, and those who had surgery versus those who did not. Systemic treatment was analyzed as chemotherapy alone, hormonal therapy alone, or both. Response to chemotherapy when used before LRT was also recorded by using the Response Evaluation Criteria in Solid Tumors (RECIST).

The treatment approach of our institute in MBC was to give upfront chemotherapy in these patients and when there was complete or near complete response, LRT was offered. More than half of our patients on the other hand were treated with LRT first and systemic treatment thereafter. The reason for this schedule was that these patients were staged with only abdominal ultrasonography (USG) and chest $\mathrm{x}$-ray, and found out with metastases after surgery when positron emission tomography (PET)/computed tomography (CT) or bone scintigraphy was performed. Postoperative locoregional RT was typically applied to patients when BCS was performed and in patients with lymph node metastasis, tumor $\geq 5 \mathrm{~cm}$ or T4 disease at initial presentation or close or positive surgical margins when modified radical mastectomy (MRM) was applied. RT was applied with tangential fields to the whole breast or CW with or without lymphatic RT. The median dose to the whole breast or CW was $50 \mathrm{~Gy}$. In case of BCS, a tumor bed boost dose of $10 \mathrm{~Gy}$ was also applied. Again a total dose of $50 \mathrm{~Gy}$ was applied to regional lymphatics when indicated. Patients with residual bone metastases after chemotherapy also received a course of external beam RT to the residual metastatic sites.

\section{Statistics}

Overall Survival (OS) was defined as the time between the date of diagnosis and the date of death or the last follow-up. Progression free Survival (PFS) was defined as the time between the date of diagnosis and the date of any failure. Survival analysis was carried out using the Kaplan-Meier method and comparisons were made using the log-rank test. The Chi-square test was used to compare patient, tumor and treatment-related characteristics according to treatment groups. Multivariate Cox regression analysis was performed using following prognostic variables for their impact on OS:
Table 1

Clinicopathologic characteristics in the entire cohort and comparisons between patients with and without locoregional treatment.

\begin{tabular}{|c|c|c|c|c|}
\hline Characteristic & $\begin{array}{l}\text { Entire cohort } \\
(n=227)\end{array}$ & $\begin{array}{l}\text { LRT } \\
(n=188)\end{array}$ & $\begin{array}{l}\text { No LRT } \\
(n=39)\end{array}$ & $p^{\mathrm{a}}$ \\
\hline Age $(y)$ & & & & 0.22 \\
\hline Median (range) & $50(27-83)$ & $50(27-83)$ & $52(29-79)$ & \\
\hline$<50$ & $109(48)$ & $94(50)$ & $15(39)$ & \\
\hline$\geq 50$ & $118(52)$ & $94(50)$ & $24(62)$ & \\
\hline Menopausal status & & & & 0.07 \\
\hline Premenopausal & $100(44)$ & $81(43)$ & 19 (49) & \\
\hline Postmenopausal & $104(46)$ & $84(45)$ & $20(51)$ & \\
\hline Perimenopausal & $23(10)$ & $23(12)$ & & \\
\hline Histology & & & & 0.086 \\
\hline IDC & $161(71)$ & $140(74)$ & $21(54)$ & \\
\hline ILC & $18(8)$ & $13(7)$ & $5(13)$ & \\
\hline Other & $46(20)$ & 35 (19) & $11(28)$ & \\
\hline Unknown & $2(1)$ & & $2(5)$ & \\
\hline T stage & & & & 0.004 \\
\hline $\mathrm{T} 1-2$ & $117(52)$ & $105(56)$ & $12(31)$ & \\
\hline T3-4 & $110(48)$ & $83(44)$ & 27 (69) & \\
\hline $\mathrm{N}$ stage & & & & 0.944 \\
\hline NO & $24(11)$ & $20(11)$ & $4(10)$ & \\
\hline $\mathrm{N}+$ & 203 (89) & $168(89)$ & $35(90)$ & \\
\hline Grade & & & & $<0.001$ \\
\hline I & $10(4)$ & $8(4)$ & $2(5)$ & \\
\hline II & $95(42)$ & $79(42)$ & $16(41)$ & \\
\hline III & 88 (39) & $81(43)$ & 7 (18) & \\
\hline Unknown & $34(15)$ & $20(11)$ & $14(36)$ & \\
\hline $\begin{array}{l}\text { Estrogen receptor } \\
\text { status }\end{array}$ & & & & 0.707 \\
\hline Positive & $153(67)$ & $125(67)$ & $28(72)$ & \\
\hline Negative & $70(31)$ & $59(31)$ & $11(28)$ & \\
\hline Unknown & $4(2)$ & $4(2)$ & & \\
\hline $\begin{array}{l}\text { Progesteron receptor } \\
\text { status }\end{array}$ & & & & 0.910 \\
\hline Positive & $152(67)$ & $125(67)$ & $27(69)$ & \\
\hline Negative & $70(31)$ & $58(31)$ & $12(31)$ & \\
\hline Unknown & $5(2)$ & $5(2)$ & & \\
\hline Her2/neu status & & & & 0.528 \\
\hline Positive & $73(32)$ & $62(33)$ & $11(28)$ & \\
\hline Negative & $146(64)$ & $119(63)$ & 27 (69) & \\
\hline Unknown & $8(4)$ & $7(4)$ & $1(3)$ & \\
\hline Triple negative tumor & & & & 0.929 \\
\hline Yes & $18(8)$ & $15(8)$ & $3(8)$ & \\
\hline No & $200(88)$ & $165(88)$ & 35 (89) & \\
\hline Unknown & $9(4)$ & $8(4)$ & $1(3)$ & \\
\hline Site(s) of metastases & & & & 0.211 \\
\hline Bone-only & $92(41)$ & $80(43)$ & $12(31)$ & \\
\hline Others & $135(59)$ & $108(57)$ & 27 (69) & \\
\hline Visceral metastases & & & & 0.08 \\
\hline No & $117(52)$ & $102(54)$ & $15(39)$ & \\
\hline Yes & $110(48)$ & $86(46)$ & $24(61)$ & \\
\hline Number of metastases & & & & 0.003 \\
\hline 1 & 43 (19) & $42(22)$ & $1(3)$ & \\
\hline$\geq 2$ & $184(81)$ & $146(78)$ & $38(97)$ & \\
\hline
\end{tabular}

Abbreviations: LRT = locoregional treatment; IDC = invasive ductal carcinoma; ILC = invasive lobular carcinoma.

Data presented as number (\%) unless otherwise specified.

a Test statistics applied to known values only.

Age at diagnosis, tumor grade, T and N stage, type of surgery, ER and PR status, number of metastases, presence of visceral metastases, bone only versus other metastases, presence of surgery, and use of RT. All statistical analysis was conducted using SPSS version 18.0 (Chicago, Illinois, USA). All analysis used the conventional $p<0.05$ level of significance.

\section{Results}

Patient, tumor, and treatment characteristics

The median follow-up time was 35 months (range, 4-149 months). The characteristics of the patients and tumors for all 227 
Table 2

Treatment characteristics and associated 5-year Kaplan-Meier overall survival and progression free survival in patients receiving locoregional treatment.

\begin{tabular}{|c|c|c|c|c|c|}
\hline Treatment & $\begin{array}{l}\text { Number of } \\
\text { patients (\%) }\end{array}$ & $\begin{array}{l}5 \text {-year } \\
\text { OS (\%) }\end{array}$ & $p^{a}$ & $\begin{array}{l}\text { 5-year } \\
\text { PFS (\%) }\end{array}$ & $p^{a}$ \\
\hline $\begin{array}{l}\text { LRT of primary lesion } \\
\qquad(n=188)\end{array}$ & & & $<0.001$ & & 0.001 \\
\hline Surgery alone & $54(29)$ & 22 & & 3 & \\
\hline RT alone & $2(1)$ & 0 & & 0 & \\
\hline Surgery and RT & $132(70)$ & 56 & & 27 & \\
\hline Type of surgery $(n=186)$ & & & 0.274 & & 0.214 \\
\hline Mastectomy & $169(91)$ & 43 & & 20 & \\
\hline BCS & $17(9)$ & 64 & & 24 & \\
\hline RT volume ( $n=134)$ & & & 0.267 & & 0.081 \\
\hline Breast/CW alone & $6(4)$ & 100 & & 67 & \\
\hline Breast/CW and lymphatic & $128(96)$ & 57 & & 26 & \\
\hline LRT schedule & & & 0.927 & & 0.760 \\
\hline Before chemotherapy & $122(65)$ & 44 & & 18 & \\
\hline After chemotherapy & $66(35)$ & 43 & & 24 & \\
\hline Systemic treatment & & & 0.004 & & 0.013 \\
\hline Chemotherapy alone & $61(32)$ & 27 & & 12 & \\
\hline Hormonal therapy alone & $9(5)$ & 75 & & 24 & \\
\hline $\begin{array}{l}\text { Chemotherapy and } \\
\text { hormonal therapy }\end{array}$ & $118(63)$ & 52 & & 23 & \\
\hline $\begin{array}{l}\text { Response to primary } \\
\text { systemic therapy }\end{array}$ & & & 0.860 & & 0.104 \\
\hline Complete response & $22(33)$ & 36 & & 34 & \\
\hline Partial response & $26(40)$ & 44 & & 33 & \\
\hline Stable disease & $14(21)$ & 54 & & 0 & \\
\hline Progression & $4(6)$ & 33 & & 25 & \\
\hline
\end{tabular}

Abbreviations: LRT = locoregional treatment; OS $=$ overall survival $\mathrm{PFS}=$ progression-free survival; RT = radiotherapy; $\mathrm{BCS}=$ breast conserving surgery; $\mathrm{CW}=$ chest wall

a Test statistics applied to known values only.

patients are listed in Table 1 . The median age at diagnosis was 50 years (range, $27-83$ years). The majority $(72 \%)$ of patients had invasive ductal carcinoma (IDC) and most (81\%) patients had grade $2-3$ tumors. The tumor size was reported as T1 -2 in $52 \%$ and T3-4 in $48 \%$. The nodal status was negative in $11 \%$ and positive in $89 \%$ of the patients. ER and PR were positive in the majority (67\%). HER2/ neu status was positive in 32\%, negative in $64 \%$ and unknown in $4 \%$ of the patients. Eight percent of patients had triple negative tumors. Of the patients, 92 (41\%) had bone-only metastases and 110 (48\%) had visceral metastases at diagnosis.

All patients received systemic treatment including chemotherapy, hormonal therapy or both. Anthracycline- and taxanebased chemotherapy was applied to 210 (93\%) patients. Hormonal therapy was given either alone or following chemotherapy to 155 (68\%) patients. In 66 patients (35\%), systemic treatment was administered before any LRT and in 122 (65\%), after LRT. The overall response rate (ORR) after primary systemic therapy was $73 \%$ with $33 \%$ complete response and $40 \%$ partial response rates. Thirty-nine patients (17\%) were without any LRT (Table 2).

In the LRT group, 2 (1\%) patients had locoregional RT alone, 54 (29\%) had surgery alone (mastectomy, $n=50$; BCS including nodal surgery, $n=4$ ) and $132(70 \%)$ had surgery (mastectomy, $n=119$; BCS including nodal surgery, $n=13$ ) followed by locoregional RT. Three (2\%) out of 50 patients with mastectomy had positive surgical margins and all others received adjuvant RT based on the presence of lymph node metastases or $\mathrm{T}$ stage of the disease. Regarding systemic therapy, $32 \%$ of patients received chemotherapy only, $5 \%$ of patients received hormonal therapy alone, whereas $63 \%$ of patients received both. RT was in the form of CW or breast and regional lymphatic irradiation in 128 out of 134 patients who received RT. Only 6 patients received breast or CW irradiation alone. Twenty-seven (12\%) patients with residual bone metastases after primary systemic therapy received consolidation RT (median dose, $30 \mathrm{~Gy}$ ) to the residual metastatic site.
The clinicopathologic characteristics for patients treated with or without LRT are shown in Table 1 . The use of LRT was significantly associated with T1-2 $(p=0.004)$ and grade III tumors $(p<0.001)$. In addition patients with solitary metastases were more likely to undergo LRT ( $p=0.003$ ) than the ones with multiple metastases. No differences between the two groups were observed concerning the age $(p=0.22)$, menopausal status $(p=0.07)$, histological subtype $(p=0.086)$, N stage $(p=0.944)$, ER $(p=0.707), \operatorname{PR}(p=0.910)$, and HER2/neu status ( $p=0.528)$, molecular subtype ( $p=0.929)$, presence of visceral metastases $(p=0.08)$ or metastatic site as bone only or with paranchymal metastasis $(p=0.211)$.

\section{Overall survival and progression-free survival}

At the time of the analysis, 37 (16\%) patients were alive with no evidence of disease, 81 (36\%) alive with disease and 109 (48\%) were dead. The reason for death was progression of the disease in 106 (47\%) and other reasons in 3 (1\%) patients. Median OS and PFS for all patients were 52 and 28 months, and 5-year OS and PFS rates were $44 \%$ and $20 \%$, respectively (Figs. 1 and 2 ).

Median OS and PFS for patients treated with LRT were 35 and 23 months, respectively. In both univariate and multivariate analysis LRT per se did not affect 5-year OS (44\% vs. $44 \%, p=0.494)$ and PFS ( $20 \%$ vs. $24 \%, p=0.339$ ) rates. Similarly, presence of surgery was not significant for 5 -year OS ( $45 \%$ vs. $42 \%, p=0.262$ ) or PFS ( $20 \%$ vs. $23 \%, p=0.182$ ). However, the 5-year OS and PFS rates were significantly higher in patients treated with locoregional RT than the ones who were not. The corresponding rates were $56 \%$ vs. $24 \%$ for OS and $27 \%$ vs. $7 \%$ for PFS ( $p<0.001$ ). Median OS was 67 months and 37 months, respectively.

The 5-year Kaplan-Meier OS rate was higher in patients treated with surgery and locoregional RT (56\%) than in patients treated with surgery alone $(22 \%)$ or RT alone $(0 \%)(p<0.001)$. PFS was $27 \%$, $3 \%$ and $0 \%$, respectively $(p<0.001)$ (Table 2$)$. Univariate analysis for both 5-year OS and PFS in patients receiving LRT revealed ER and PR positivity, and non-triple negative tumors as the favorable

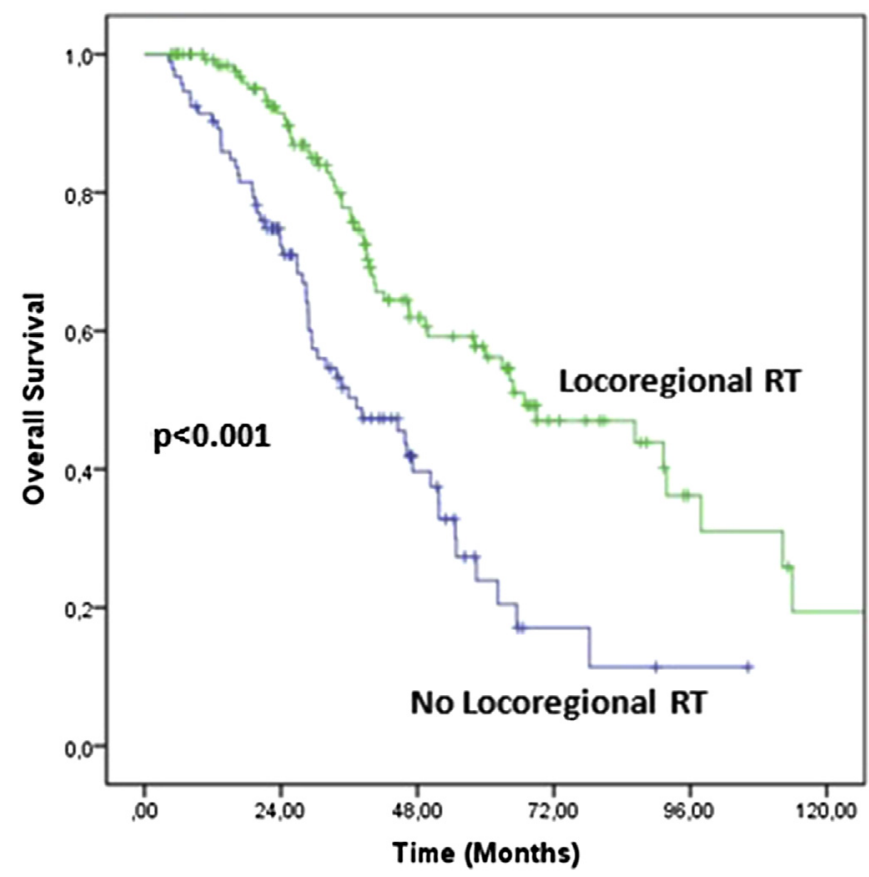

Fig. 1. Kaplan-Meier overall survival of patients presented with $M B C$ according to locoregional RT. 


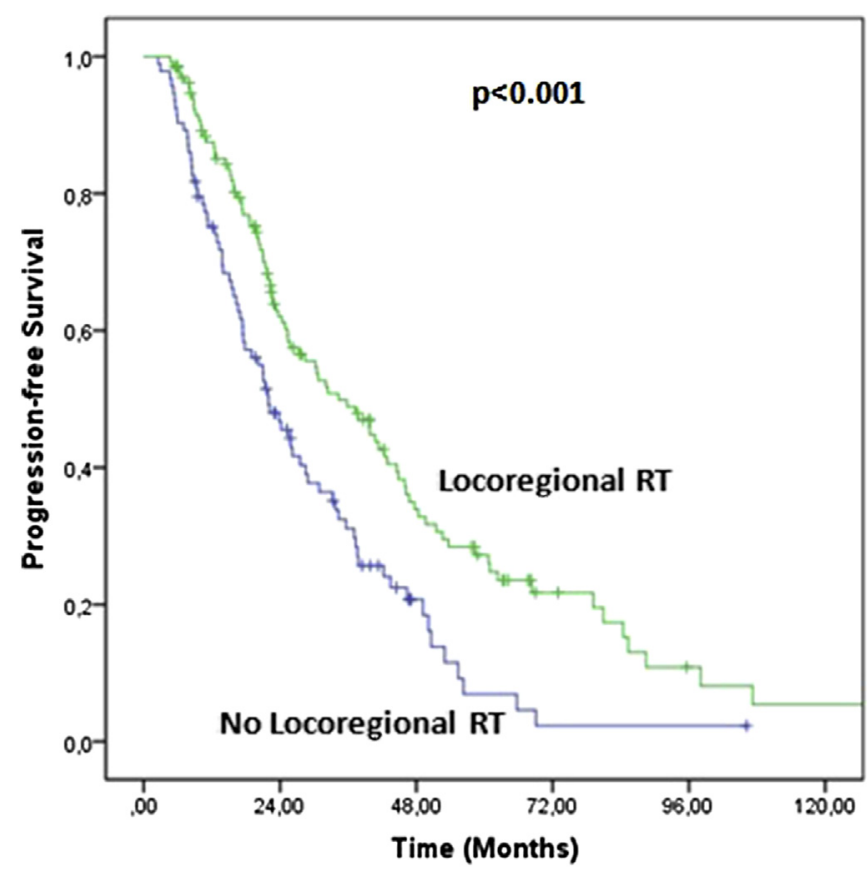

Fig. 2. Kaplan-Meier progression free survival of patients presented with MBC according to locoregional RT.

prognostic factors (Table 3 ). Having T1-2 tumors was significantly associated with 5 -year OS ( $54 \%$ vs. $30 \%, p=0.001$ ) whereas there was an only trend for PFS ( $25 \%$ vs. $13 \%, p=0.068$ ). In addition, type of systemic therapy was significantly associated with 5-year OS and PFS with better survival rates when hormonal therapy was given (Table 2). Though not statistically significant, bone only metastases ( $52 \%$ vs. $36 \%, p=0.055$ ), solitary metastases ( $55 \%$ vs. $41 \%, p=0.064$ ) and non-visceral metastases ( $53 \%$ vs. $33 \%, p=0.066)$ were associated with a better OS and there was statistically significant difference in PFS for solitary metastasis versus multiple metastases (37\% vs. $16 \%, p=0.035)$. Bone only metastases ( $26 \%$ vs. $13 \%, p=0.136$ ) and non-visceral metastases ( $25 \%$ vs. $14 \%, p=0.145$ ) were not statistically significant for PFS. Histology was only associated with PFS (Table 3). Age at diagnosis, menopausal status, grade, $\mathrm{N}$ classification, HER2/neu status, timing of LRT, response to primary chemotherapy, type of surgery, and RT volume did not affect OS or PFS (Tables 2 and 3).

The results of the multivariate Cox proportional hazards model is presented in Table 4. The presence of LRT again did not affect the OS rates. However locoregional RT significantly decreased the risk of death. This risk was 2.5 times higher when RT was omitted. Additionally, we found that advanced $\mathrm{T}$ stage (hazard ratio [HR] 0.423; 95\% confidence interval [CI], 0.269-0.667; $p<0.001$ ) and triple negative subtype (hazard ratio [HR] 0.422; 95\% confidence interval $[\mathrm{CI}], 0.183-0.972 ; p=0.043$ ) significantly affected OS rates.

\section{Discussion}

Role of LRT in MBC is a matter of debate in the recent years. Though there are several retrospective studies and a metaanalysis the answer of this issue has not been give yet [6-17,21-33]. The majority of retrospective trials revealed the benefit of local treatment mainly by surgery, to an extent similar to renal cell, colorectal, ovarian and gastric carcinoma [6-17]. The 3-year survival rates were $17-79 \%$ without and $28-95 \%$ with surgery, respectively $[6,11,12,21-23]$. Contrary to surgery, studies
Table 3

Univariate analysis for overall survival and progression free survival of potential prognostic factors in patients receiving locoregional treatment.

\begin{tabular}{|c|c|c|c|c|}
\hline Characteristic & $\begin{array}{l}\text { 5-year } \\
\text { OS (\%) }\end{array}$ & $p^{a}$ & $\begin{array}{l}\text { 5-year } \\
\text { PFS (\%) }\end{array}$ & $p^{a}$ \\
\hline Age (y) & & 0.684 & & 0.926 \\
\hline$<50$ & 41 & & 20 & \\
\hline$\geq 50$ & 48 & & 20 & \\
\hline Menopausal status & & 0.593 & & 0.751 \\
\hline Premenopausal & 43 & & 19 & \\
\hline Postmenopausal & 46 & & 20 & \\
\hline Perimenopausal & 48 & & 24 & \\
\hline Histology & & 0.162 & & 0.045 \\
\hline IDC & 47 & & 24 & \\
\hline ILC & 31 & & 8 & \\
\hline Other & 44 & & 17 & \\
\hline Unknown & 27 & & 0 & \\
\hline T stage & & 0.001 & & 0.068 \\
\hline $\mathrm{T} 1-2$ & 54 & & 25 & \\
\hline T3-4 & 30 & & 13 & \\
\hline $\mathrm{N}$ stage & & 0.335 & & 0.956 \\
\hline NO & 49 & & 19 & \\
\hline $\mathrm{N}+$ & 43 & & 20 & \\
\hline Grade & & 0.073 & & 0.186 \\
\hline I-II & 51 & & 25 & \\
\hline III & 37 & & 16 & \\
\hline Estrogen receptor status & & 0.002 & & 0.018 \\
\hline Positive & 53 & & 23 & \\
\hline Negative & 28 & & 11 & \\
\hline Progesteron receptor status & & 0.015 & & 0.026 \\
\hline Positive & 51 & & 24 & \\
\hline Negative & 31 & & 11 & \\
\hline Her2/neu status & & 0.679 & & 0.193 \\
\hline Positive & 44 & & 18 & \\
\hline Negative & 45 & & 20 & \\
\hline Triple negative tumor & & 0.002 & & 0.001 \\
\hline Yes & 0 & & 0 & \\
\hline No & 47 & & 21 & \\
\hline Site(s) of metastases & & 0.055 & & 0.136 \\
\hline Bone-only & 52 & & 26 & \\
\hline Others & 36 & & 13 & \\
\hline Visceral metastases & & 0.066 & & 0.145 \\
\hline No & 53 & & 25 & \\
\hline Yes & 33 & & 14 & \\
\hline Number of metastases & & 0.064 & & 0.035 \\
\hline 1 & 55 & & 37 & \\
\hline$\geq 2$ & 41 & & 16 & \\
\hline
\end{tabular}

Abbreviations: LRT = locoregional treatment; IDC = invasive ductal carcinoma; ILC = invasive lobular carcinoma.

a Test statistics applied to known values only.

evaluating the role of RT in the setting of metastatic disease are limited and the question whether the consolidation RT had additional beneficial effect on oncological outcomes has not been clarified yet $[7,8,12,13,15-17,24-27,30]$.

Local control was thought to be a critical factor for OS in $\mathrm{MBC}$ Several mechanisms have been proposed for this increase in survival. The most accepted one is that metastatic cancer cells have

Table 4

Multivariable Cox regression analysis of overall survival.

\begin{tabular}{llll}
\hline Variable & Hazard ratio & (95\% confidence interval) & $p$ Value \\
\hline $\begin{array}{l}\text { T classification } \\
\text { T1-2 }\end{array}$ & 0.423 & $0.269-0.667$ & \\
$\quad$ T3-4 (Ref) & 1 & & $<0.001$ \\
Locoregional RT & & $1.463-4.254$ & \\
$\quad$ No & 2.495 & & 0.001 \\
$\quad$ Yes (Ref) & 1 & $0.183-0.972$ & \\
$\quad \begin{array}{l}\text { Triple negative tumors } \\
\quad \text { No }\end{array}$ & 0.422 & & 0.043 \\
$\quad$ Yes (Ref) & 1 & & \\
\hline
\end{tabular}

Abbreviations: $\mathrm{RT}=$ radiotherapy. 
numerous effects on the immune system and removal of the primary tumor in patients with $\mathrm{MBC}$ may reduce immunosuppressive factors and improve patient's immune system [31]. Additionally, surgical removal of the primary tumor may decrease the tumor burden and development of new metastatic lesions and increase the efficacy of systemic treatment [34]. Locoregional RT on the other hand may also enhance immunity against cancer [35]. The induction of antitumor immunity of RT is believed to be by abscopal effect of ionizing irradiation that produced inhibition of metastases outside the treatment field [36,37]. On the other hand, several studies showed that residual locoregional disease might be a source of metastases, and aggressive local control could decrease ongoing distant dissemination and risk of death in high-risk patients $[38,39]$.

In this retrospective study, we tried to evaluate the role of LRT in patients with MBC. The primary aim of our study was to investigate whether adjuvant RT further increased survival rates in MBC patients who were also treated with systemic treatment and surgery to the primary tumor. We found that adjuvant locoregional RT led to an increase in OS and PFS rates. The 5-year OS and PFS rates with or without RT were $56 \%$ vs. $24 \%$ and $24 \%$ vs. $7 \%$, respectively. The median survival of patients treated with locoregional RT was 67 months versus 37 months for patients without RT $(p<0.001)$ and the risk of death was found to be 2.5 times higher when RT was omitted.

The majority of retrospective studies to $\mathrm{MBC}$ were come from population-based database and data regarding hormone receptor status, margin status, and RT details were not available. Also, there are several selection biases both in patient and treatment characteristics which are usual in retrospective series. LRT in these retrospective series was more frequently used in selected patients with better prognostic profile [7-11,13,17,22]. These patients were significantly younger, had fewer comorbidities, more often had hormone receptor positive disease, had a lower stage and lower grade tumors, had fewer sites of metastases, less often with visceral metastases, less likely to have symptomatic metastases and more often treated with combined locoregional RT and/or systemic treatment $[6-9,11,13,21,40]$. Similar to the literature, the use of LRT was more common in our patients with better prognostic features including T1-2 tumors and solitary metastases. No significant differences could be found between patients receiving LRT or not in terms of age, menopausal status, histological subtype, N stage, ER, PR, and HER2/neu status, and sites of metastases in our study. However it was found that there was significantly higher percentage of patients with grade 3 tumors in LRT $(+)$ arm.

Numerous retrospective studies have reported that surgical removal of intact primary is associated with a significantly improved survival [6-17]. These studies are summarized in Table 5. Babiera et al. [21] and Neuman et al. [24] on the other hand reported a trend towards increased survival, but it was statistically not significant. However, it is not clear yet which patients would most likely benefit from surgery. Two population-based studies showed that compared to systemic treatment only, R0 resection offered the best survival benefit $[6,8]$. In these studies, majority of patients had total mastectomy (40\%-77\%) with axillary lymph node dissection and free margins was related with improved survival comparing partial mastectomy or BCS $[6,7,11]$. Contrary to the literature, we found no significant difference in survival with the type of surgery. There was no difference in terms of OS and PFS between mastectomy and BCS. Consistent with our data, a few retrospective studies did not showed clear survival benefit of LRT $[11,23,25]$. Bafford et al. [11] analyzed 147 patients with primary $\mathrm{MBC}$ and found that the median OS was not different between the surgery and the non-surgery group $(p=0.093)$. Additionally, Leung et al. [25] showed that when patients presenting MBC receive chemotherapy, LRT did not improve survival.
Similar to the retrospective studies, there are several metaanalysis and reviews evaluating the role of surgery in patients presenting with MBC [31-33]. A metaanalysis by Petrelli et al. [32] showed that surgery of the primary tumor improved survival with a $30 \%$ reduction in the risk of death. These results were particularly significant if local surgery was associated with systemic therapy and RT which highlighted the importance of multimodality approach. Ruiterkamp et al. [31] in another metaanalysis reported that HR for overall mortality varied from 0.47 to 0.71 and pooled HR was 0.65 in favor of surgery. More recently, Harris et al. [33] reported that 3-year survival was significantly increased in patients undergoing surgery with $22 \%$ OS rates when systemic therapy alone compared with $40 \%$ when surgery was added.

The role of locoregional RT in MBC is another matter of debate. In the literature, improvement in OS or disease-free survival with locoregional RT was reported in six studies $[7,8,12,17,30,41]$. However in another 3 studies there was not significant survival advantage with RT $[13,22,25]$. Rapiti et al. [7] showed that patients who had surgery were more likely to have local RT compared with patients who did not and found that RT was significantly associated with improved survival. The form of RT in that particular study however was not stated whether irradiation was delivered in the adjuvant setting or to treat the metastatic sites. Vlastos et al. [41] on the other hand showed that patients treated with BCS were significantly with increased OS following RT. In another two studies, exclusive locoregional RT was significantly associated with improved survival on multivariate analysis and results were similar with retrospective surgical studies [12,26]. Le Scodan et al. [12] found that the 3-year OS was $43.4 \%$ for patients who were treated with locoregional treatment. LRT in that study was in the form of exclusive RT in 78\% of patients, surgery followed by RT in $13 \%$ and surgery alone in $9 \%$ of patients. Geiger et al. [42] in a recent study, demonstrated that the greatest benefit was seen in patients who received all the treatment modalities including surgery, systemic therapy, and RT. In our study only two patients treated with exclusive RT. The majority of our patients were treated with adjuvant RT after surgery and it was found that locoregional RT per se might affect both OS and PFS rates supporting the data of the other retrospective series in favor of locoregional RT.

There are a lot of clinical, biological and treatment characteristics that affect the outcome of patients with MBC. Age, performance status, ER/PR/HER2/neu status, number and type of metastatic sites, use of systemic treatment (chemotherapy/hormonal therapy), type of surgery and surgical margins have been identified to be prognostic factors (Table 5). Favorable prognostic factors in MBC were reported to be negative surgical margins, bone-only metastasis, solitary or oligometastasis, positive ER/PR status and having systemic treatment. The unfavorable factors on the other hand were positive surgical margins, HER2/neu overexpression, triple negative tumors or presence of visceral metastases [6-17,21-30]. In our study, consistent with the literature, we found that LRT was associated with improved OS, particularly in patients with ER and PR positive tumors, non-triple negative tumors, T1-2 tumors, and having hormonal therapy. After stratifying by site of metastases, patients who had bone-only, solitary or non-visceral metastases showed not statistically significant but a trend for improved OS rates with the addition of locoregional RT. However, there was statistically significant difference in PFS for solitary metastases when RT was added to breast/CW \pm regional sites. Distinctly from other studies, we did not found statistically significant impact of age and number of metastases on OS or PFS, who were treated with LRT [17].

The optimal timing of LRT and systemic treatment and the prognostic value of the response of the primary tumor to systemic treatment has not been solved yet. Rao et al. [43] demonstrated that patients who underwent surgery more than 3 months of diagnosis 


\begin{tabular}{|c|c|c|c|c|c|c|c|c|c|}
\hline Author (Year) & Study type & Patient/treatment characteristics & $\begin{array}{l}\text { Number of } \\
\text { patients }\end{array}$ & $\begin{array}{l}\text { Median } \\
\text { follow-up } \\
\text { (mo) }\end{array}$ & $\begin{array}{l}\text { Median } \\
\text { age (years) }\end{array}$ & Overall survival (median) & $\mathrm{HR}$ & $95 \% \mathrm{CI}$ & $\begin{array}{l}\text { Prognostic factors } \\
\text { (multivariate analysis) }\end{array}$ \\
\hline $\begin{array}{r}\text { Khan [6] } \\
(2002)\end{array}$ & Population-based & $\begin{array}{l}\text { Primary surgery ( } 57 \%) ; 38 \% \mathrm{PM} \text {; } \\
62 \% \mathrm{TM} ; 63 \% \mathrm{RT} \text {. } \\
\text { Surgerygroup: less visceral metastases, } \\
\text { more } 1 \text { metastatic site }\end{array}$ & 16,023 & NR & 62.5 & $\begin{array}{l}\text { Free margins vs. no surgery } \\
\text { Positive margins vs. no surgery } \\
\text { 3-y survival: PM } 27.7 \% \text {; TM } \\
31.8 \% \text {; No surgery } 17.3 \% \\
(p<0.0001)\end{array}$ & $\begin{array}{l}0.61 \\
0.75\end{array}$ & $\begin{array}{l}0.58-0.65 \\
0.71-0.79\end{array}$ & $\begin{array}{l}\text { Surgery, number of } \\
\text { metastatic sites, } \\
\text { type of metastatic disease } \\
\text { (visceral vs. soft tissue), } \\
\text { chemotherapy, hormonal } \\
\text { therapy, margin status }\end{array}$ \\
\hline $\begin{array}{l}\text { Babiera [21] } \\
\quad(2006)\end{array}$ & Hospital-based & $\begin{array}{l}\text { Primary surgery (39\%); } 48 \% \text { PM; } 52 \% \text { TM; } \\
50 \% \text { definitive surgery. } \\
\text { Surgery group: younger, less nodal involvement, } \\
\text { fewer sites of metastases, more liver metastases, } \\
\text { more HER2/neu+, more chemotherapy }\end{array}$ & 224 & 32.1 & 52 & $\begin{array}{l}\text { Surgery vs. no surgery } \\
32.1 \mathrm{mo} \text { (all) }\end{array}$ & 0.50 & $0.21-1.19$ & $\begin{array}{l}\text { Number of metastatic } \\
\text { sites, HER2/neu status }\end{array}$ \\
\hline $\begin{array}{r}\text { Rapiti [7] } \\
\text { (2006) }\end{array}$ & Population-based & $\begin{array}{l}\text { Primary surgery ( } 42 \%) \text {. } \\
\text { Surgery group: younger, lower T stage, lower } \\
\mathrm{N} \text { stage, more } 1 \text { metastatic site, less visceral } \\
\text { metastases, more local RT, less chemotherapy }\end{array}$ & 300 & NR & $\begin{array}{l}67.4 \\
\text { (mean) }\end{array}$ & $\begin{array}{l}\text { Free margins vs. No surgery } \\
5 \text {-y CSS: } \\
\text { Surgery-unknown margins } \\
\text { (26\%): } 12 \% \\
\text { Surgery-positive margins } \\
\text { (26\%): } 16 \% \\
\text { Surgery-negative margins } \\
\text { (48\%): } 27 \% \\
\text { No surgery (58\%): } 12 \% \\
(p=0.0002)\end{array}$ & 0.60 & $0.4-1.0$ & $\begin{array}{l}\text { Surgery, age, method } \\
\text { of discovery, nodal status, } \\
\text { visceral metastasis, } \\
\text { CNS metastases, hormonal } \\
\text { therapy, surgical margins }\end{array}$ \\
\hline $\begin{array}{l}\text { Fields [9] } \\
(2007)\end{array}$ & Hospital-based & $\begin{array}{l}\text { Primary surgery ( } 46 \%) ; 14 \% \text { definitive surgery. } \\
\text { Surgery group: younger, smaller tumors, } \\
\text { less bone metastases }\end{array}$ & 409 & 142 & 57 & $\begin{array}{l}\text { Surgery vs. No surgery } \\
26.8 \text { mo vs. } 12.6 \text { mo } \\
(p<0.0001)\end{array}$ & 0.53 & $0.42-0.67$ & Surgery, site of metastases \\
\hline $\begin{array}{l}\text { Gnerlich [8] } \\
\quad(2007)\end{array}$ & Population-based & $\begin{array}{l}\text { Primary surgery ( } 47 \%) \text {. } \\
\text { Surgery group: younger, smaller tumors }(<5 \mathrm{~cm}) \text {, } \\
\text { more Grade III, more ER+/PR+ }\end{array}$ & 9734 & NR & 62 & $\begin{array}{l}\text { Surgery vs. No surgery } \\
36 \text { mo vs. } \\
21 \mathrm{mo}(p<0.001)\end{array}$ & 0.62 & $0.59-0.66$ & NR \\
\hline $\begin{array}{l}\text { Blanchard [10] } \\
\quad(2007)\end{array}$ & Other & $\begin{array}{l}\text { Primary surgery }(61 \%) \text {. } \\
\text { Surgery group: older, smaller tumors }(\leq 2 \mathrm{~cm}) \text {, } \\
\text { more ER+/PR+, no visceral metastases, } \\
\text { more } 1 \text { metastatic site }\end{array}$ & 395 & NR & $\begin{array}{l}60.4 \\
\text { (mean) }\end{array}$ & $\begin{array}{l}21.7 \text { mo (all) Surgery vs. } \\
\text { No surgery } \\
27.1 \text { vs. } 16.8 \text { mo }(p<0.0001)\end{array}$ & 0.71 & $0.56-0.91$ & $\begin{array}{l}\text { Surgery, number } \\
\text { of metastases, } \\
\text { ER status, PR status }\end{array}$ \\
\hline $\begin{array}{r}\text { Cady [23] } \\
(2008)\end{array}$ & $\begin{array}{l}\text { Hospital-based } \\
\text { (Matched pair } \\
\text { analysis) }\end{array}$ & $\begin{array}{l}\text { Primary surgery ( } 38 \% \text { ). } \\
\text { Surgery group: younger, more ER+, more bone } \\
\text { only metastases, more oligometastatic disease, } \\
\text { good response to initial systemic therapy }\end{array}$ & 622 & NR & 60 & $\begin{array}{l}\text { Surgery vs. No surgery } \\
33 \text { mo vs. } 18 \mathrm{mo}(p<0.0001)\end{array}$ & NR & & \\
\hline $\begin{array}{l}\text { Hazard [22] } \\
\quad(2008)\end{array}$ & Hospital-based & $\begin{array}{l}\text { Primary surgery }(42 \%) \\
\text { Surgery group: younger, less HR + tumors, } \\
\text { more local RT }\end{array}$ & 111 & 26.9 & $\begin{array}{l}52.7 \\
\text { (mean) }\end{array}$ & $\begin{array}{l}\text { Surgery vs. No surgery Local } \\
\text { control } 82 \% \text { vs. } 34 \%(p=0.001)\end{array}$ & 0.798 & $0.40-1.52$ & $\begin{array}{l}\mathrm{NR} \text {; chest wall control was } \\
\text { associated with improved } \\
\text { OS regardless of surgey } \\
\text { (HR } 0.42, p=0.0002 \text { ) }\end{array}$ \\
\hline $\begin{array}{l}\text { Ruiterkamp [13] } \\
\text { (2009) }\end{array}$ & Population-based & $\begin{array}{l}\text { Primary surgery ( } 40 \%) \text {. } \\
\text { Surgery group: younger, smaller tumors, } \\
\text { less multiple sites, less concomitant diseases, } \\
\text { more RT ( } 34 \% \text { vs. } 10 \% \text { ), more systemic therapy }\end{array}$ & 728 & NR & $\begin{array}{l}\text { NR } \\
(>5075 \%)\end{array}$ & $\begin{array}{l}\text { Surgery vs. No surgery } \\
31 \text { mo vs. } 14 \mathrm{mo}(p<0.0001)\end{array}$ & 0.62 & $0.51-0.76$ & $\begin{array}{l}\text { Surgery, age, number of } \\
\text { metastatic sites, } \\
\text { systemic treatment }\end{array}$ \\
\hline $\begin{array}{l}\text { Bafford [11] } \\
\quad(2009)\end{array}$ & Hospital-based & $\begin{array}{l}\text { Primary surgery ( } 41 \%) \text {. } \\
\text { Surgery group: fewer sites of metastases, more RT }\end{array}$ & 147 & NR & 49.2 & $\begin{array}{l}\text { Surgery vs. No surgery } \\
4.13 \text { years vs. } 2.36 \text { years } \\
(p=0.003)\end{array}$ & 0.47 & NR & $\begin{array}{l}\text { Surgery (patients operated } \\
\text { upon before diagnosis of } \\
\text { metastatic disesase), ER+, } \\
\text { HER2/neu+, liver metastasis, } \\
\text { CNS metastasis }\end{array}$ \\
\hline $\begin{array}{l}\text { Shien [14] } \\
\quad(2009)\end{array}$ & Hospital-based & $\begin{array}{l}\text { Primary surgery ( } 47 \%) ; 94 \% \text { definitive } \\
\text { surgery; } 88 \% \text { chemotherapy. } \\
\text { Surgery group: younger, more bone and } \\
\text { soft tissue metastases, more hormonal therapy }\end{array}$ & 344 & 33 & 54 & $\begin{array}{l}\text { Surgery vs. No surgery } \\
27 \text { mo vs. } 22 \text { mo }(p=0.049)\end{array}$ & 0.89 & NR & Surgery, age \\
\hline $\begin{array}{l}\text { Le Scodan }[12] \\
\text { (2009) }\end{array}$ & Hospital-based & $\begin{array}{l}\text { Group A ( } n=320 \text { ): LRT ( } 78 \% \text { exclusive LRRT, } \\
\text { 13\% surgery + adjuvant RT, 9\% surgery alone) }\end{array}$ & 581 & 39 & NR & $\begin{array}{l}\text { Group A vs. Group B } \\
32 \text { mo vs. } 21 \text { mo }\end{array}$ & 0.70 & $0.58-0.85$ & \\
\hline
\end{tabular}


Group B $(n=261)$ : No LRT.

lower $\mathrm{N}$ stage, more non-visceral metastases,
Group A patients had a lower T stage,

fewer metastatic sites, more systemic treatment

No chemotherapy;

RT vs. No RT; median survival

$17 \mathrm{mo}(p=0.36)$

$17 \mathrm{mo}(p=0.36)$

No hormon thy vs.

No hormonal therapy;

median survi

\begin{tabular}{|c|c|c|c|c|c|c|c|c|c|}
\hline $\begin{array}{l}\text { Neuman }[24] \\
\quad(2010)\end{array}$ & Hospital-based & $\begin{array}{l}\text { Primary surgery ( } 37 \%) ; 71 \% \text { definitive } \\
\text { surgery; } 13 \% \text { postoperative RT. } \\
\text { Surgery group: more HER2/neu-, } \\
\text { smaller tumors, more solitary metastases }\end{array}$ & 186 & 52 & 53 & $\begin{array}{l}\text { Surgery vs. No surgery } \\
(p=0.10) \\
35 \mathrm{mo} \text { (all) }\end{array}$ & 0.71 & $0.47-1.06$ & $\begin{array}{l}\text { Site of metastatic disease } \\
\text { (bone and visceral metastase } \\
\text { ER/PR/HER2/neu status }\end{array}$ \\
\hline $\begin{array}{l}\text { Bourgier [26] } \\
\quad(2010)\end{array}$ & Hospital-based & $\begin{array}{l}\text { Group } 1(n=147) \text { : LRRT alone. } \\
\text { Group } 2(n=92) \text { : Surgery } \pm \text { LRRT. } \\
\text { Group 1: higher T and N stage, more }>1 \\
\text { metastatic sites, more primary systemic therapy }\end{array}$ & 239 & 6.5 years & NR & $\begin{array}{l}\text { 3-y MPFS: } 20 \% \text { vs. } 39 \% \\
\text { 3-y OS: } 39 \% \text { vs. } 57 \%\end{array}$ & NR & & $\begin{array}{l}\text { Age, ER status, number of } \\
\text { metastatic sites }\end{array}$ \\
\hline $\begin{array}{l}\text { Pathy [15] } \\
\text { (2011) }\end{array}$ & Hospital-based & $\begin{array}{l}\text { Primary surgery ( } 37 \%) ; 34 \% \mathrm{RT} \text {; } \\
83 \% \text { systemic treatment. } \\
\text { Surgery group: more smaller tumors, } \\
\text { less nodal involvement, more hormonal therapy }\end{array}$ & 375 & NR & 50 & $\begin{array}{l}\text { Surgery vs. No surgery } \\
12.2 \text { (all); } 21.3 \text { vs. } 10.1 \\
2 \text {-y OS: } 46.3 \text { vs. } 21.2\end{array}$ & 0.72 & $0.56-0.94$ & $\begin{array}{l}\text { Surgery, free surgical } \\
\text { margins, age }\end{array}$ \\
\hline $\begin{array}{l}\text { Pérez-Fidalgo } \\
\text { [16] (2011) }\end{array}$ & Hospital-based & $\begin{array}{l}\text { Primary surgery ( } 59 \%) ; 83 \% \text { mastectomy } \\
\text { with } \mathrm{AD} ; 46.3 \% \text { adjuvant } \mathrm{RT} \text {. } \\
\text { Surgery group: better general condition, } \\
\text { more } 1 \text { metastatic site, more bone only } \\
\text { metastases, less visceral metastases }\end{array}$ & 208 & 29.68 & $\begin{array}{l}55.9 \\
\text { (mean) }\end{array}$ & $\begin{array}{l}\text { Surgery vs. No surgery } \\
40.4 \text { vs. } 24.3 \text { mo }(p<0.001) \\
\text { Patients with visceral } \\
\text { metastases }(p=0.005) \text { and } \\
\text { bone metastases }(p=0.79)\end{array}$ & 0.52 & $0.35-0.77$ & Surgery, ER status \\
\hline $\begin{array}{l}\text { Rosche [27] } \\
\quad(2011)\end{array}$ & Hospital-based & $\begin{array}{l}\text { Primary surgery ( } 57 \%) ; 11 \% \text { local RT. } \\
\text { Surgery group: younger, more } 1 \text { metastatic site, } \\
\text { less lymphatic metastases, more RT }\end{array}$ & 61 & NR & 60 & $\begin{array}{l}\text { Surgery vs. No surgery } \\
\text { OS }(p=0.439) \\
\text { PFS }(P=0.142)\end{array}$ & NR & NR & \\
\hline $\begin{array}{l}\text { Dominici [28] } \\
\quad(2011)\end{array}$ & Population-based & $\begin{array}{l}\text { Non-surgery patients ( } n=236) \text { were matched } \\
\text { to surgery patients }(n=54) \text {.Surgery group: younger, } \\
\text { less }>1 \text { metastatic sites, more endocrine therapy }\end{array}$ & 290 & NR & $\begin{array}{l}\text { NR } \\
(>5065 \%)\end{array}$ & $\begin{array}{l}\text { Surgery vs. No surgery } \\
3.5 \text { years vs. } 3.4 \text { years }\end{array}$ & 0.94 & $0.84-1.05$ & None \\
\hline $\begin{array}{l}\text { Rashaan [29] } \\
\quad(2012)\end{array}$ & Hospital-based & $\begin{array}{l}\text { Primary surgery ( } 35 \%) \\
\text { Surgery group: younger, no medication use, } \\
\text { lower T stage, lower grade, less metastases } \\
\text { at multiple sites }\end{array}$ & 171 & NR & NR & Surgery vs. No surgery & 0.9 & $0.6-1.4$ & Age, comorbidity \\
\hline $\begin{array}{l}\text { Nguyen [17] } \\
\quad(2012)\end{array}$ & Population-based & $\begin{array}{l}\text { LRT ( } 52 \%): 67 \% \text { surgery alone, } 22 \% \text { RT alone, } \\
11 \% \text { both LRT group: younger, smaller tumors, } \\
\text { less nodal involvement, more limited metastatic } \\
\text { disease, more asymptomatic metastases }\end{array}$ & 733 & 1.9 years & 58 & $\begin{array}{l}\text { LRT vs. No LRT } \\
5 \text {-y OS } 21 \% \text { vs. } 14 \% \\
(p<0.001) \\
5 \text {-y PFS } 72 \% \text { vs. } 46 \% \\
(p<0.001)\end{array}$ & 0.78 & $0.64-0.94$ & $\begin{array}{l}\text { LRT, surgical margins, } \\
\text { chemotherapy, } \\
\text { hormonal treatment }\end{array}$ \\
\hline $\begin{array}{l}\text { Khanfir [30] } \\
\text { (2013) }\end{array}$ & Hospital-based & $\begin{array}{l}\text { Primary surgery (17\%); } 95 \% \text { chemotherapy or } \\
\text { hormonal therapy; LRRT }(n=23)\end{array}$ & $\begin{array}{l}332(39 \% \\
\text { synchronous } \\
\text { metastasis) }\end{array}$ & NR & 50.5 & $\begin{array}{l}5 \text {-y OS in synchronous } \\
\text { metastases: } \\
\text { Surgery vs. No surgery } \\
21 \% \text { vs. } 11 \% \text { ( } p=0.0003) \\
\text { RT vs. No RT } 25 \% \text { vs. } 11 \% \\
(p=0.02)\end{array}$ & NR & & $\begin{array}{l}\text { Age, performance status, } \\
\text { type of metastatic disease }\end{array}$ \\
\hline
\end{tabular}

Abbreviations: $\mathrm{PM}=$ partial mastectomy; $\mathrm{TM}=$ total mastectomy; $\mathrm{RT}=$ radiotherapy; $\mathrm{NR}=$ not reported; $\mathrm{ER}=$ estrogen receptor; $\mathrm{PR}=$ progesterone receptor; $\mathrm{HR}=$ hormone receptor; $\mathrm{OS}=$ overall survival; $T=$ tumor;

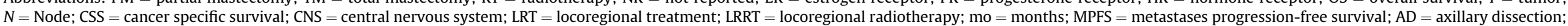
$\mathrm{PFS}=$ progression-free survival. 
had improved PFS, with no difference in OS. However, systemic treatment including chemotherapy and/or hormonal therapy was applied to all patients. Babiera et al. [21] had also reported that the patients with surgical resection were more likely to receive chemotherapy as first line treatment. Bafford et al. [11] showed a benefit of surgery only in the patients diagnosed with MBC before surgery. Cady et al. [23] suggested that most of the survival advantage for patients undergoing surgery is explained by case selection bias, meaning that patients with a good response to initial systemic therapy are also more likely to undergo surgery than those with a poor response. There are numerous studies showing that timing of surgery was no significant prognostic factor for patients with MBC $[11,22,24,40]$. Similar to the reports in literature we could not find the importance of timing of LRT on survival rates. Also, we could not find any significant differences according to response to initial systemic treatment. However our treatment policy is to consider LRT especially in patients who showed complete or good partial response mainly in metastatic sites and this might lead to a selection bias and may confound the results.

Two prospective randomized controlled trials regarding the role of LRT in MBC have been presented at the 2013 San Antonio Breast Cancer Symposium [18,19]. The one from Tata Memorial Hospital included $350 \mathrm{MBC}$ patients who randomized to LRT $\operatorname{arm}(n=173)$ or no-LRT $\operatorname{arm}(n=177)$ after objective tumor response to six cycles of anthracycline based chemotherapy [18]. Patients in the LRT arm were treated with partial or complete surgical removal of their breasts and surgical removal of axillary lymph nodes, followed by RT. There was no difference in OS between those who received LRT and those who did not receive LRT with a median follow-up of 17 months. A second trial from Turkey included $278 \mathrm{MBC}$ patients randomized to surgery $\operatorname{arm}(n=140)$ or no-surgery $\operatorname{arm}(n=138)$ [19]. With a follow-up time of 54 months, the overall survival rate was $35 \%$ in the surgery arm and $31 \%$ in the no-surgery arm $(p=0.24)$. However, patients with solitary bone only metastases had statistically significant survival benefit with surgery compared with no surgery $(p=0.03)$. Both of the 2 trials were with short follow-ups and it is difficult to make a conclusion based on these results. The long-term follow-up of these studies will provide more conclusive results in the future.

In conclusion, though it is a retrospective study and has several limitations, our results led us to think that a subset of patients with MBC who received adjuvant locoregional RT might have a survival advantage. We suggest a multimodality approach including systemic therapy, surgery and RT especially for patients with favorable prognostic factors such as ER/PR positive and smaller tumors, bone only metastases, solitary metastases and non-visceral metastases. In patients with large and triple negative tumors, new and different treatment options including more advanced targeted chemotherapies or alternative RT modalities should be considered. Phase 3 trials testing the efficacy of locoregional RT after surgery will highlight whether there is an absolute need of RT or not in MBC.

\section{Funding}

None.

\section{Conflict of interest statement}

There is no conflict of interest.

\section{References}

[1] Sant M, Allemani C, Berrino F, Coleman MP, Aareleid T, Chaplain G, et al. Breast carcinoma survival in Europe and the United States. Cancer 2004;100:715-22.
[2] Ellis MJ, Hayes DF, Lippman ME. Treatment of metastatic breast cancer. In: Harris J, et al., editors. Diseases of the breast. 2nd ed. Philadelphia: Williams and Wilkins; 2000. p. 749-97.

[3] Wood WC, Muss HB, Solin LJ, Olopade OI. Malignant tumors of the breast. In: DeVita Jr VT, Hellman S, Rosenberg SA, editors. Cancer principles and practice of oncology. 7th ed. Philadelphia: Lippincott Williams; 2005. p. 1415-78.

[4] Singletary SE, Walsh G, Vauthey JN, Curley S, Sawaya R, Weber KL, et al. A role for curative surgery in the treatment of selected patients with metastatic breast cancer. Oncologist 2003;8:241-51.

[5] Colozza M, de Azambuja E, Personeni N, Lebrun F, Piccart MJ, Cardoso F. Achievements in systemic therapies in the pregenomic era in metastatic breast cancer. Oncologist 2007;12:253-70.

[6] Khan SA, Stewart AK, Morrow M. Does aggressive local therapy improve survival in metastatic breast cancer? Surgery 2002;132:620-6 [discussion 626-627].

[7] Rapiti E, Verkooijen HM, Vlastos G, Fioretta G, Neyroud-Caspar I, Sappino AP et al. Complete excision of primary breast tumor improves survival of patients with metastatic breast cancer at diagnosis. J Clin Oncol 2006;24:2743-9.

[8] Gnerlich J, Jeffe DB, Deshpande AD, Beers C, Zander C, Margenthaler JA. Surgical removal of the primary tumor increases overall survival in patients with metastatic breast cancer: analysis of the 1988-2003 SEER data. Ann Surg Oncol 2007; 14:2187-94.

[9] Fields RC, Jeffe DB, Trinkaus K, Zhang Q, Arthur C, Aft R, et al. Surgical resection of the primary tumor is associated with increased long-term survival in patients with stage IV breast cancer after controlling for site of metastasis. Ann Surg Oncol 2007; 14:3345-51.

[10] Blanchard DK, Shetty PB, Hilsenbeck SG, Elledge RM. Association of surgery with improved survival in stage IV breast cancer patients. Ann Surg 2008;247: $732-8$.

[11] Bafford AC, Burstein HJ, Barkley CR, Smith BL, Lipsitz S, Iglehart JD, et al. Breast surgery in stage IV breast cancer: impact of staging and patient selection on overall survival. Breast Cancer Res Treat 2009;115:7-12.

[12] Le Scodan R, Stevens D, Brain E, Floiras JL, Cohen-Solal C, De La Lande B, et al. Breast cancer with synchronous metastases: survival impact of exclusive locoregional radiotherapy. J Clin Oncol 2009;27:1375-81.

[13] Ruiterkamp J, Ernst MF, van de Poll-Franse LV, Bosscha K, Tjan-Heijnen VC, Voogd AC. Surgical resection of the primary tumour is associated with improved survival in patients with distant metastatic breast cancer at diagnosis. Eur J Surg Oncol 2009;35:1146-51.

[14] Shien T, Kinoshita T, Shimizu C, Hojo T, Taira N, Doihara H, et al. Primary tumor resection improves the survival of younger patients with metastatic breast cancer. Oncol Rep 2009;21:827-32.

[15] Pathy NB, Verkooijen HM, Taib NA, Hartman M, Yip CH. Impact of breast surgery on survival in women presenting with metastatic breast cancer. $\mathrm{Br} \mathrm{J}$ Surg 2011;98:1566-72.

[16] Pérez-Fidalgo JA, Pimentel P, Caballero A, Bermejo B, Barrera JA, Burgues O, et al. Removal of primary tumor improves survival in metastatic breast cancer. Does timing of surgery influence outcomes? Breast 2011;20:548-54.

[17] Nguyen DH, Truong PT, Alexander C, Walter CV, Hayashi E, Christie J, et al. Can locoregional treatment of the primary tumor improve outcomes for women with stage IV breast cancer at diagnosis? Int J Radiat Oncol Biol Phys 2012;84:39-45.

[18] R. Badwe, V. Parmar, R. Hawaldar, N. Nair, R. Kaushik, S. Siddique, et al. Surgical removal of primary breast tumor and axillary lymph nodes in women with metastatic breast cancer at first presentation: a randomized controlled trial. Presented at: 2013 San Antonio breast cancer symposium; December 10-14, 2013; San Antonio, TX. Abstract S2-02.

[19] A. Soran, V. Ozmen, S. Ozbas, H. Karanlik, M. Muslumanoglu, A. Igci, et al., Early follow up of a randomized trial evaluating resection of the primary breast tumor in women presenting with de novo stage IV breast cancer; Turkish study (protocol MF07-01). Presented at: 2013 San Antonio breast cancer symposium; December 10-14, 2013; San Antonio, TX. Abstract S2-03.

[20] https://clinicaltrials.gov.

[21] Babiera GV, Rao R, Feng L, Meric-Bernstam F, Kuerer HM, Singletary SE, et al. Effect of primary tumor extirpation in breast cancer patients who present with stage IV disease and an intact primary tumor. Ann Surg Oncol 2006;13: 776-82.

[22] Hazard HW, Gorla SR, Scholtens D, Kiel K, Gradishar WJ, Khan SA. Surgical resection of the primary tumor, chest wall control, and survival in women with metastatic breast cancer. Cancer 2008;113:2011-9.

[23] Cady B, Nathan NR, Michaelson JS, Golshan M, Smith BL. Matched pair analyses of stage IV breast cancer with or without resection of primary breast site. Ann Surg Oncol 2008;15:3384-95.

[24] Neuman HB, Morrogh M, Gonen M, Van Zee KJ, Morrow M, King TA. Stage IV breast cancer in the era of targeted therapy: does surgery of the primary tumor matter? Cancer 2010;116:1226-33.

[25] Leung AM, Vu HN, Nguyen KA, Thacker LR, Bear HD. Effects of surgical excision on survival of patients with stage IV breast cancer. J Surg Res 2010;161:83-8.

[26] Bourgier C, Khodari W, Vataire AL, Pessoa EL, Dunant A, Delaloge S, et al. Breast radiotherapy as part of loco-regional treatments in stage IV breast cancer patients with oligometastatic disease. Radiother Oncol 2010;96: 199-203.

[27] Rosche M, Regierer AC, Schwarzlose-Schwarck S, Weigel A, Bangemann N, Schefe JH, et al. Primary tumor excision in stage IV breast cancer at diagnosis without influence on survival: a retrospective analysis and review of the literature. Onkologie 2011;34:607-12. 
[28] Dominici L, Najita J, Hughes M, Niland J, Marcom P, Wong YN, et al. Surgery of the primary tumor does not improve survival in stage IV breast cancer. Breast Cancer Res Treat 2011;129:459-65.

[29] Rashaan ZM, Bastiaannet E, Portielje JE, van de Water W, van der Velde S, Ernst MF et al. Surgery in metastatic breast cancer: patients with a favorable profile seem to have the most benefit from surgery. Eur J Surg Oncol 2012;38:52-6.

[30] Khanfir A, Lahiani F, Bouzguenda R, Ayedi I, Daoud J, Frikha M. Prognostic factors and survival in metastatic breast cancer: a single institution experience. Rep Pract Oncol Radiother 2013;18:127-32.

[31] Ruiterkamp J, Voogd AC, Bosscha K, Tjan-Heijnen VC, Ernst MF. Impact of breast surgery on survival in patients with distant metastases at initial presentation: a systematic review of the literature. Breast Cancer Res Treat 2010;120:9-16.

[32] Petrelli F, Barni S. Surgery of primary tumors in stage IV breast cancer: an updated meta-analysis of published studies with meta-regression. Med Oncol 2012;29:3282-90.

[33] Harris E, Barry M, Kell MR. Meta-analysis to determine if surgical resection of the primary tumour in the setting of stage IV breast cancer impacts on survival. Ann Surg Oncol 2013;20:2828-34.

[34] Dauplat J, Le Bouedec G, Pomel C, Scherer C. Cytoreductive surgery for advanced stages of ovarian cancer. Semin Surg Oncol 2000;19:42-8.

[35] Formenti SC, Demaria S. Combining radiotherapy and cancer immunotherapy: a paradigm shift. J Natl Cancer Inst 2013:105:256-65.

[36] Ohba K, Omagari K, Nakamura T, Ikuno N, Saeki S, Matsuo I, et al. Abscopal regression of hepatocellular carcinoma after radiotherapy for bone metastasis. Gut 1998;43:575-7.
[37] Wersall PJ, Blomgren H, Pisa P, Lax I, Kälkner KM, Svedman C. Regression of non-irradiated metastases after extracranial stereotactic radiotherapy in metastatic renal cell carcinoma. Acta Oncol 2006;45:493-7.

[38] Overgaard M, Hansen PS, Overgaard J, Rose C, Andersson M, Bach F, et al. Postoperative radiotherapy in high-risk premenopausal women with breast cancer who receive adjuvant chemotherapy. N Engl J Med 1997;337: 949-55.

[39] Early Breast Cancer Trialists' Collaborative Group (EBCTCG). Effects of radiotherapy and of differences in the extent of surgery for early breast cancer on local recurrence and 15-year survival: an overview of the randomized trials. Lancet 2005;366:2087-106.

[40] Ruiterkamp J1, Voogd AC, Bosscha K, Roukema JA, Nieuwenhuijzen GA, TjanHeijnen VC, et al. Presence of symptoms and timing of surgery do not affect the prognosis of patients with primary metastatic breast cancer. Eur J Surg Oncol 2011;37:883-9.

[41] Vlastos G, Smith DL, Singletary SE, Mirza NQ Tuttle TM, Popat RJ, et al. Longterm survival after an aggressive surgical approach in patients with breast cancer hepatic metastases. Ann Surg Oncol 2004;11:869-74.

[42] Geiger S, Cnossen JA, Horster S, DiGioia D, Heinemann V, Stemmler HJ. Longterm follow-up of patients with metastatic breast cancer: results of a retrospective, single-center analysis from 2000 to 2005. Anticancer Drugs 2011;22: 933-9.

[43] Rao R, Feng L, Kuerer HM, Singletary SE, Bedrosian I, Hunt KK, et al. Timing of surgical intervention for the intact primary in stage IV breast cancer patients. Ann Surg Oncol 2008;15:1696-702. 